\title{
CHARACTERISTICS OF SUCCESSFUL LOCAL BLENDED PROGRAMS IN THE CONTEXT OF THE SLOAN-C PILLARS
}

\author{
Jacqueline F. Moloney \\ University of Massachusetts Lowell \\ Charmaine P. Hickey \\ University of Massachusetts Lowell \\ Amy L. Bergin \\ University of Massachusetts Amherst \\ Judith Boccia \\ University of Massachusetts Lowell \\ Kathleen Polley \\ University of Massachusetts Boston \\ Jeannette E. Riley \\ University of Massachusetts Dartmouth
}

\begin{abstract}
Drawing on the University of Massachusetts experience in developing successful blended local programs, this paper suggests guiding principles that include mission-driven responsiveness to local contexts and partnerships; using low-cost marketing strategies available through local relationships and brand; attending to students' preferences for blending face-to-face and online services and instruction throughout the college experience; supporting faculty in working with partners to develop local blended programs; and providing activities that anchor students to the campus and program.
\end{abstract}

\section{KEYWORDS}

Localness, Blended, Principles, Competitive Advantage, Women's Studies Minor, Master's In Educational Administration, Registered Nurse To Bachelor Of Science In Nursing, Master's In Business Administration

\section{INTRODUCTION}

During the early nineties, the internet entered higher education with great force as faculty and institutions raced to integrate the World Wide Web into courses and programs. According to the Sloan-C Growing By Degrees report [1] both asynchronous online teaching and web-enhanced teaching expanded rapidly during that period and continues to do so. However, the report also suggests that blended learning, 
instruction that combines online instruction with face to face instruction, has the great potential to become - beyond face-to-face and online learning - a third, high growth opportunity for increasing access to higher education.

To realize that potential, The Sloan Foundation, an early supporter of asynchronous online education, began funding institutions to develop blended learning nearly three years ago. As a result, numerous papers and conceptual frameworks have emerged around teaching and learning and administrative approaches to supporting blended learning [2, 3, 4]. This article summarizes research funded by The Sloan Foundation to study how blended learning and online learning can meet the needs of local constituencies, a 'localness' approach to online education. The researchers wrote four case studies of programs that exemplified the best practices of local blended learning programs and then analyzed the cases to identify characteristics common to the four cases.

\section{BACKGROUND ON BLENDED LEARNING AND LOCALNESS}

The Sloan-Consortium's (Sloan-C), mission is to "help learning organizations continually improve quality, scale, and breadth according to their own distinctive missions, so that education will become a part of everyday life, accessible and affordable for anyone, anywhere, at any time, in a wide variety of disciplines" [5]. To advance that mission and to create a framework for conducting research on online education, the Consortium developed the Sloan-C Five Pillars of Quality Online Education: Access, Learning Effectiveness, Student Satisfaction, Faculty Satisfaction and Cost Effectiveness. The research conducted on the cases drew heavily on this framework.

As mentioned previously, Sloan-C researchers have identified blended learning as a new area prime for expansion, yet very much under-studied by practitioners in the field [3]. Blended learning is described as "both simple and complex. At its simplest, blended learning is the thoughtful integration of classroom face-to-face learning experiences with online learning experiences.... At the same time, there is considerable complexity in its implementation with the challenge of virtually limitless design possibilities and applicability to so many contexts“ [4]. In a document written by a number of blended learning experts and edited by Janet C. Moore of the Sloan Consortium [6], twelve principles for blended learning environments are outlined from the perspectives of institutions and administration, learners, teachers, student services, and information technology. From institutional and administrative perspectives, it is imperative to begin with a shared vision of how technology can improve teaching and learning, and develop efficiencies in cost and scalability. From the perspective of learners, blended learning should identify ways to meet the needs of individual learners and provide continuous support for role adjustment-moving from a primarily on-campus to an environment integrated with online. For teachers, blended environments must provide active institutional support and recognition for faculty; ensure learning design appropriately integrates face to face and online components; promote metacognitive reflection on the process of learning; and provide timely feedback and clear expectations for response time. From the perspective of student services, integration of student services for on-campus and online students is imperative. From an information technology perspective, an early plan for course development must be in place; continuous training and support must be provided; and appropriate technology must be chosen [6].

The research reported in this article draws on the work of the researchers mentioned above by adding a new dimension to the previous studies called localness. A. Frank Mayadas, President of The Sloan Consortium and Project Director for The Sloan Foundation, coined this new term to capture what he thinks is a competitive advantage for institutions across the country. Mayadas wrote in a white paper on the topic: "We'd like to use Asynchronous Learning Networks coupled with blending to get some focus 
back on locality and localness strategies”. He further envisioned, “a strong ALN and blended effort would further permit the institution to expand its effective radius of influence, say from 50 miles to more like 100 or even 150 miles” [7].

While many leaders suspect that blended learning has the potential to provide students with the best of both the internet and face to face experiences in the classroom, the localness strategy suggested by Mayadas has yet to be defined. In a paper prepared for the 2005 Sloan-C Summer Workshop, authors George Otte and Mary Niemiec [3] point to the need for cases or pilots that can be studied to examine conceptual frameworks in a more systematic way.

For this reason, four case studies were conducted to explore common characteristics of programs that blend online learning and extra-curricular activities with face to face experiences to meet the needs of local constituencies. A qualitative study of the cases was conducted to determine if these successful programs had underlying characteristics that made them successful. The common characteristics were then organized into a framework for developing successful local blended programs based on the Sloan-C Pillars.

In this article, we describe the methodologies used to conduct this research, a framework of characteristics common to the cases and a condensed version of each case. Finally, we will provide a set of suggested guiding principles for developing successful blended local programs.

\section{METHODOLOGY}

\section{A. Case Selection}

The cases were selected from four of the five University of Massachusetts' campuses located across the state (the Medical School was not included in the study). All of the programs are offered in collaboration with UMassOnline, the system's portal to online education. Cases were selected from each participating campus. All of the cases summarized a program that provided access for a local company, constituency or organization; used some element of blended courses, services or programs and some mix of each; and had some evidence of enhancing student achievement through blended learning.

The UMass Amherst's Professional Master's in Business Administration was selected because of its intelligent use of satellite locations, including corporate sites, to supplement online courses and services with face-to-face courses and services. UMass Boston's Registered Nurse to Bachelor of Science in Nursing program was selected for its highly structured use of blended services and instruction to increase retention of adult learners in an online program. UMass Lowell's partnership with the Lawrence School System to develop and deliver a customized Master's in Educational Administration online degree (Leadership in Educational Advancement Program, LinEAP) was selected as an exemplar of customizing programs to suit the needs of a local organization. UMass Dartmouth's Women's Studies Minor blended program was chosen for its unique ability to provide access to adult women returning to college in the Dartmouth area by supporting students in taking a mix of online courses and face to face courses to complete their degrees. A graphic summary of these programs along with other selected information is provided in Table 1. 


\begin{tabular}{|c|c|c|c|c|c|}
\hline Program & $\begin{array}{l}\text { Distinguishing } \\
\text { Localness } \\
\text { Program } \\
\text { Characteristic }\end{array}$ & $\begin{array}{c}\text { First } \\
\text { Launched } \\
\text { (full launch } \\
\text { or with some } \\
\text { blend) }\end{array}$ & $\begin{array}{c}\text { Program } \\
\text { Composition }\end{array}$ & $\begin{array}{l}\text { One Important } \\
\text { Aspect of This } \\
\text { Blended Program }\end{array}$ & $\begin{array}{c}\text { Selected } \\
\text { Demographics }\end{array}$ \\
\hline $\begin{array}{c}\text { Amherst: PMBA } \\
\text { (Professional } \\
\text { MBA) }\end{array}$ & $\begin{array}{l}\text { MBA program that } \\
\text { makes use of } \\
\text { satellite and } \\
\text { employer locations }\end{array}$ & 2001 & $\begin{array}{c}37 \text { credits; } \\
\text { choice of online } \\
\text { or } f 2 f\end{array}$ & $\begin{array}{l}\text { Large scale increases } \\
\text { student options for } \\
\text { format and location to } \\
\text { address learning } \\
\text { effectiveness, } \\
\text { satisfaction and } \\
\text { access }\end{array}$ & $\begin{array}{l}750 \text { matriculated } \\
\text { students } \\
\text { including } 50 \text { at } \\
\text { one employer } \\
\text { and } 60 \text { at another } \\
\text { employer. }\end{array}$ \\
\hline $\begin{array}{l}\text { Boston: } \\
\text { RN to BS }\end{array}$ & $\begin{array}{c}\text { Online BS in } \\
\text { Nursing uses } \\
\text { cohort model with } \\
\text { mandatory } \\
\text { technology } \\
\text { orientation }\end{array}$ & 2004 & $\begin{array}{l}\text { Includes } 5,6- \\
\text { credit nursing } \\
\text { courses: } 1 \\
\text { entirely online; } 4 \\
\text { blended }\end{array}$ & $\begin{array}{l}\text { Articulation } \\
\text { agreements and } \\
\text { partnerships with } \\
\text { community colleges } \\
\text { and area employers }\end{array}$ & $\begin{array}{l}25 \text { students in } \\
\text { Spring } 2006 \\
\text { cohort }\end{array}$ \\
\hline $\begin{array}{l}\text { Dartmouth: WMS } \\
\text { (Women's } \\
\text { Studies Minor) }\end{array}$ & $\begin{array}{l}\text { Degree Minor } \\
\text { motivating local } \\
\text { students to } \\
\text { complete their } \\
\text { degrees }\end{array}$ & 2003 & $\begin{array}{l}6 \text { courses; } 3 \\
\text { required and } 3 \\
\text { WMS electives }\end{array}$ & $\begin{array}{l}\text { Increased access to } \\
\text { degree completers in } \\
\text { Dartmouth area, } \\
\text { particularly those in } \\
\text { Business and Nursing } \\
\text { programs }\end{array}$ & $\begin{array}{l}\text { Average of } 28 \\
\text { enrolled in WMS } \\
\text { minor. Summer } \\
2006 \text { yielded } 78 \\
\text { enrollments in } \\
\text { WMS courses. }\end{array}$ \\
\hline $\begin{array}{l}\text { Lowell: LinEAP } \\
\text { (Leadership in } \\
\text { Educational } \\
\text { Administration) }\end{array}$ & $\begin{array}{l}\text { Customized M.Ed. } \\
\text { developed for } \\
\text { Lawrence School } \\
\text { District }\end{array}$ & 2003 & $\begin{array}{c}6 \text { courses: all } \\
\text { blended to some } \\
\text { extent }\end{array}$ & $\begin{array}{l}\text { Intentional integration } \\
\text { of Lawrence leaders } \\
\text { and circumstances } \\
\text { into pedagogy aimed } \\
\text { at growing a cadre of } \\
\text { district leaders }\end{array}$ & $\begin{array}{l}25 \text { completers in } \\
\text { first cohort; } 14 \\
\text { enrolled in } \\
\text { second (current) } \\
\text { cohort }\end{array}$ \\
\hline
\end{tabular}

Table 1: UMass Programs Profiled as Cases that Characterize Successful Local Blended Programs

A case-writer most closely associated with the program was identified and recruited to write from each campus. The case writers composed a description of the program and used a prescribed set of guiding interview questions to explore one or more perspectives from three categories of stakeholders: students, faculty members, and administrators/corporate partners.

\section{B. Cross-case Analysis}

To conduct this research, the case studies were combined and analyzed using qualitative research software called NVivo ${ }^{\circledR}$, a software application designed to aid in qualitative research. Qualitative research extracts meaning from a range of textual information such as field or case notes, articles, and indepth interview or focus group transcripts. "NVivo ${ }^{\circledR}$ software offers researchers the opportunity for analysis and insight at a whole new level with a powerful, intelligent application that helps with managing, shaping, and analyzing virtually any information” [8]. NVivo ${ }^{\circledR}$ served as the workhorse, in place of folders, highlighters, and post-its, to help the researchers manage and analyze the individual case data.

The Sloan-C Pillars served as a framework for creating a preliminary set of pre-determined codes that served as a guide for our analysis of the case data. Once analysis began, the researchers examined the cases for other descriptive characteristics or codes.

The researchers who conducted the cross case analysis are experienced online education program developers and researchers. Each case was then imported into an NVivo ${ }^{\circledR}$ document file. The constantcomparative method of data analysis [9] was used to examine the cases for best practices and characteristics. The first level of analysis [10] was performed by thoroughly reading each case at least 
once, but more often several times. This allows the reader to obtain a general understanding of the case. A second level of analysis involved the coordinator beginning with the first level of coding and matching instances to the Sloan-C Five Pillar Codes. A third level of analysis involved taking a different crosssection of the data. The coordinator and the PI used the tools provided by NVivo ${ }^{\circledR}$ to search for and select appropriate passages containing particular words or phrases such as 'mix' or 'blend'.

Simultaneous to the data analysis in $\mathrm{NVivo}{ }^{\circledR}$, the coordinators used Inspiration ${ }^{\circledR}$ Software to develop a visual model of the themes emerging from the data. This encouraged and supported a combination of inductive and deductive reasoning during the analysis.

\section{OVERVIEW OF THE FINDINGS}

Each of the cases studied presented unique approaches to blending the learning environment to respond to the needs of various local constituencies. Yet, there were several characteristics that were common to all of the cases. The researchers searched identified key characteristics by searching both for frequency of mention as well as the emergence of the characteristics across the four cases.

The pillar framework was used as the basis for grouping the characteristics of the successful local blended learning programs. The resulting graphic shown below provides a visualization of the characteristics of the successful programs.

Findings are represented visually in Figure 1.

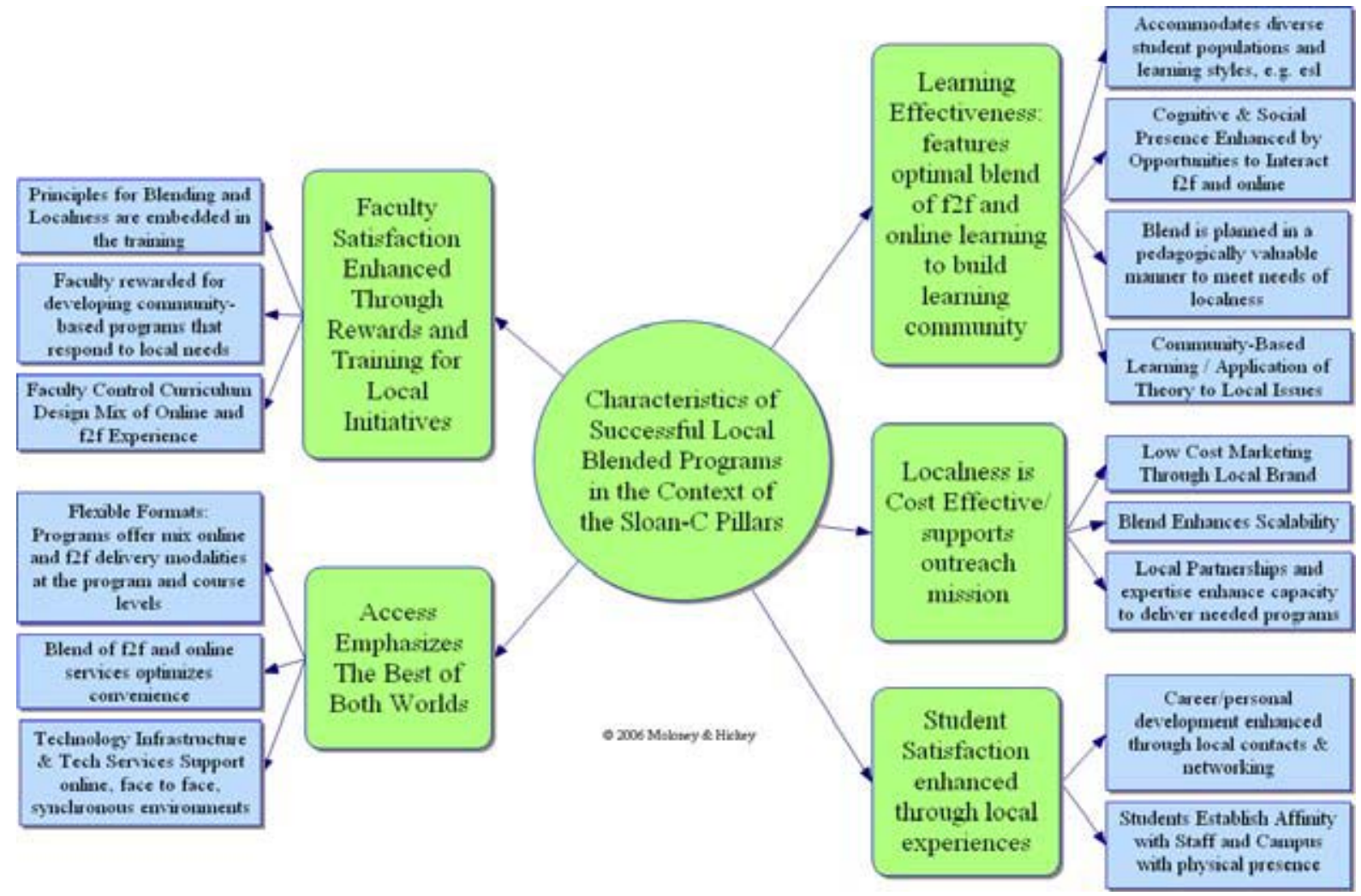

Figure 1. Characteristics of Successful Local Blended Programs in the Context of the Sloan-C Pillars 
As shown, central to the graphic is the characteristic that each of the programs started from and that was the intentional use of blended learning to respond to local needs. The remainder of the characteristics are grouped under a pillar to provide greater definition of the attributes of the pillar in localness terms. The next sections of this paper provide specific examples of the characteristics.

\section{A. Localness Supports Outreach Mission and Facilitates Cost Effective Solutions}

Cases illustrated that localness contributes in unique ways to cost effectiveness and institutional commitment. Three major findings emerged in this area.

First, each case demonstrated how using local blended programs enhanced the institution's capacity to fulfill its outreach mission to various constituencies in a way that neither face-to-face nor online education programs alone could do. UMass Amherst was able to work with companies to develop blended programs that utilized on-site, satellite and online courses to enable employees to access their programs. UMass Lowell's Education program enabled the campus to support a struggling inner-city school system's need for school leaders, very much a part of the campus mission. UMass Dartmouth's Women's Studies program and UMass Boston's Nursing Program provided opportunities for adult learners to return to college to earn degrees needed to advance in the workforce.

Second, all of the cases were able to take advantage of low cost marketing through the local brand of the campus. The Lowell Campus case best illustrated this with the LinEAP program when a marketing and advertising type of synergy was created among the program faculty, staff and students, the university and the Lawrence Public School District, local politicians, and students' families. The Lowell case indicated,

...the program is advertised within the Lawrence Public Schools through the Lawrence Teachers Union and the Lawrence Administrators' Association. The Superintendent also hosted a dinner midway through the first cohort to acknowledge and celebrate the partnership with UML, and recognize the faculty and students involved. Civic and educational leaders were invited and indistrict press coverage was provided. The first cohort was similarly feted at a lavish graduation celebration attended by their families and faculty; again, press coverage within the district was used to share news of the program [11].

In the condensed cases below the reader will find evidence that each of the exploited local knowledge of their programs to market to local/regional organizations and businesses. For example, UMass Boston worked closely with local hospitals and health care providers to recruit students into their program.

Third, all of the programs offered a cost-effective solution to their local constituencies by either reducing tuition, or by providing high quality, customized programs at an affordable cost. For example, UMass Amherst's PMBA provided blended, sometimes customized programs to regional companies at a rate that fell well below what it would have cost the company to develop their own training. Similarly, UMass Lowell was able to discount tuition for the Lawrence Schools because the cost of services was reduced by using the cohort model. Not only did the school system get the benefit of reduced tuition, it was able to generate a pipeline of high quality school administrators by linking successful completion of the education program to tuition subsidies and contracts “...a pre-program meeting that includes signing a contract that... [indicates the teacher must] remain in the district for 3 years, or pay back the costs of the courses to the district” [11].

Fourth, the cases showed that local partnerships and expertise enhanced the capacity for the campuses to 
develop and deliver the kind of programs needed by the local region. Polley wrote that in Boston's case, "The Program seeks to achieve this by forging partnerships with the community colleges in Massachusetts, designing culturally competent RN specific curriculum... It is critical that these goals are achieved while decreasing institutional barriers to remote students at an affordable cost” [12].

Finally, the cases describe success in scaling their programs by reaching out to local constituencies in this new way. For example, UMass Boston's Nursing program scaled by $30 \%$ annually after blending its program and tailoring its curriculum to local health care providers. UMass Amherst's PMBA scaled to the largest online program in the state by using the blend of services, courses at satellite and corporate sites.

\section{B. Access Emphasizes the Best of Both Worlds}

Three primary findings about the Access Pillar emerged from the analysis of the cases. First, each case exemplified different types of flexible formats, offering a mix of online and face to face delivery modalities at both the program and course levels. The Amherst case writer remarked that “...students feel the flexibility of choosing the course format that works best for them was a deciding factor in choosing the PMBA program...” [13].

The second characteristic that emerged as having a significant effect on the success of the program was an emphasis on blended services. In other words, students had the opportunity, and in some instances the requirement, to obtain services face to face and/or online based on which was more convenient or effective for students. For example, as an introduction to the blended learning environment, orientations or information sessions were offered by each campus with face to face, online, or blended options, providing a smooth transition to this modality, while simultaneously offering a connection to the campus. Other services that may be considered are enrollment, library services, alumni events, and campus communications, for example.

Third, cases indicated that technology infrastructure and technical services support was offered online, face to face, and in synchronous environments. Cases showed us that technological support online should be complemented by personal support on campus or over the phone. Selection of the type of technology used should also lend itself to blending. Centra or Horizon-Wimba are examples of types of technology that have the potential to work as a positive tool for students, faculty, and the local region. The Boston case showed us that "strategies to avert or ameliorate technology problems included having a six-hour face to face technology orientation.... A face to face meeting fosters a connection between the students, and a personal connection is made with the Director” [12].

\section{Student Satisfaction Enhanced through Local Experiences}

Two primary findings emerged from examination of student satisfaction in the cases. First, localness makes a unique contribution to the enhancement of career and personal development through local contacts made by participation in the program and blended learning and through opportunities for networking. The LinEAP program case best represented this benefit by highlighting a student opinion that "at the same time that she found the online learning convenient and powerful, she 'loved' the face to face meetings embedded in each course. The close professional connections established...continue...as a support network in her current leadership role” [11].

A second aspect of the Student Satisfaction pillar illustrated that students establish an affinity with the campus and the campus staff through physical presence that is a characteristic of localness. Students are 
more satisfied when they can create that connection with someone on campus, whether a staff person, faculty, or other students who they can share with. The Boston case explains that,

The second face to face meeting...to form a book club. They develop a presentation that will be presented to the faculty...at a luncheon....allows students to develop their presentation skills and meet with the faculty in a very casual setting.... The students have enjoyed and benefited from dialogue with the faculty [12].

\section{Faculty Satisfaction Enhanced through Rewards and Training for Local Initiatives}

Indications of faculty satisfaction in the cases yielded unique aspects of localness. Three primary findings highlighted these aspects. First, the cases indicated that principles for blended learning and localness are embedded in training that faculty receive from the campuses. One example of this was provided in the Amherst case. Bergin quoted one faculty member as stating, "The faculty who teach in the program have monthly brown bag lunches to discuss hot topics, teaching tools and applications, etc. which gives us time together to discuss ways to better improve the program” [13].

Second, faculty are rewarded for developing community-based programs that respond to local needs. Dartmouth's Women's Studies Program acknowledged progress by faculty toward the blended model through stipends.

Faculty who responded to the request [to develop online courses] demonstrated their rationale for putting a particular course online and then if the proposal was approved by the WMS curriculum committee, the faculty member received a $\$ 3500$ development grant [funded by UMassOnline]. [Then]... the WMS program turned to PCE for continued development funding and arranged for faculty who developed new courses for fully online delivery to be paid an additional $\$ 1000$ the first time the course was taught [14].

Third, faculty in successful blended programs are able to control the design mix of online and face to face experiences for themselves and students. This control is enhanced by the faculty member's knowledge of the local context/culture, which in turn, enhances their teaching experience. One faculty member from Amherst explains the benefit of teaching in a blended environment, "A pure online format makes it difficult to connect with students and establish a more personal relationship; professors must work harder to connect with online students so having the ability to make personal connections with students face-toface makes it a better teaching experience for me" [13].

Teaching experience can also be enhanced by the model chosen for the program such as the cohort model. From a LinEAP student point of view, the cohort model was “...valued....with its mixed grade levels as a valuable framework for understanding the entire school system and a structure for building community among participants” [11]. Additionally, a LinEAP faculty member “...acknowledged the value of the cohort for building community and a commitment to helping and sharing with colleagues” [11]. Another LinEAP faculty member

...believes the cohort model and customized content of LinEAP is one of its most attractive features for faculty members. The shared common experiences in curriculum and instruction the group brings to the course work give him a foundation on which to build his course material and an opportunity to focus on critical issues. He is convinced the cohort helps people get through a challenging program by forging a group identity and providing peer support for learning. He also thinks that meeting in school environments provides a highly relevant setting for face to face classes, and gives teachers from different grade levels the chance to experience the work 
environments of colleagues who teach at other levels. Paul believes LinEAP is a strong model of leadership development because it is a holistic program, based in a single district, utilizing a cohort of peers who meet both face to face for community building, and asynchronously where they have the time to reflect on their learning [11].

\section{E. Learning Effectiveness Features Optimal Blend of F2F and Online Learning to Build Learning Community}

Learning effectiveness is one of the key features of the quality pillars. Four major outcomes emerged from analysis of the campus cases. First, effective local blended learning accommodates diverse student populations and learning styles. For example, English-As-A-Second-Language (ESL) students are of special consideration when focusing on learning effectiveness for all populations in the local area.

Second, both cognitive and social presence are enhanced by opportunities to interact face to face and online [2]. Students appreciate the flexibility in choice and the way that they can adapt blended learning to address their most effective way of learning. An Amherst student is quoted as saying, "This program allows me the opportunity to choose different learning environments so I know what works best for me.... I feel I learn best when I can sit with people and see their expressions and body language” [13]. Another example supports the value of the optimal mix in blended learning. One student

...liked the convenience of the online learning but found the face to face meetings indispensable. Indeed, she and a group of classmates set up a face to face study group during the online sessions as a way to support their learning and socialize. She thought the combination of the two learning modes accommodated different learning styles in the cohort, and provided each member a variety of ways to master course content [11].

Third, blended learning is planned in a pedagogically valuable manner to meet the needs of localness. As illustrated in the Boston case, local students in this particular program require a significant amount of technology training and confidence-building prior to the beginning of their program. This barrier provides both a challenge and an opportunity for a teaching moment for students that sets the tone of their entire program. "While familiarizing themselves with the tools used in online learning students build bridges with their peers which are then expanded through the design of the curriculum" [12].

Fourth and finally, learning effectiveness is enhanced by combining community-based learning, and application of theory to local issues, for a real-world learning experience. This theme is illustrated throughout the cases. Boston students enjoy the mix of community based learning, partnerships and planned pedagogy that is based in the context of the students' work environment. Of the Amherst PMBA Program, Bergin writes that the "...distinction and partnership accomplishment between UMass and a corporate partner serves as a perfect example of how the non-traditional model of the...program is having a significant local impact on employee satisfaction, performance, retention, and overall organizational improvement" [13]. The deep roots of the Lawrence LinEAP in the community provide the best example of community-based learning for learning effectiveness. Boccia describes the reaction of Dr. Laboy, the Superintendent:

...in the current climate where urban school leaders are difficult to find, he considered it essential to build a cadre of leaders with deep stakes in the community, who commit to building a future for Lawrence youth, and leaving a legacy in the district.... All the...issues have national scale, and LinEAP applies those to the local setting in an entirely appropriate way [11]. 


\section{CASE SUMMARIES}

This framework, as illustrated in Figure 1, was developed by extracting particular instances from the full case as written by each case writer. In this article, we have included condensed versions of the cases that preserve and highlight the localness of each. These represent a "collage" of the four cases, each written in the unique and different voice of the campus case-writer. The condensed versions of these cases are presented below.

\section{A. Professional MBA (PMBA) Program: UMass Amherst Case Writer Amy Bergin}

The Professional MBA (PMBA) program at the University of Massachusetts Amherst allows students the option of taking courses face-to-face at one of our Massachusetts campus locations (Shrewsbury, Holyoke, Pittsfield) or online (WebCT Vista) or a combination of both formats throughout the life of the 37-credit curriculum. In addition, PMBA students have access to the same University services as full-time residency-based MBA students and may participate in any Isenberg or University sponsored events.

The PMBA program currently enrolls 750 students from every state and 15 foreign countries, and enjoys an average annual growth rate of $25 \%$. Hosting, maintenance and support of the learning portal (now WebCT Vista), hardware, third party software applications, and 24 hour technical support to students and staff for the PMBA Program are contracted from UMASSOnline.

The PMBA program attracts many corporate clients. One advantage of the PMBA program cited by these corporate clients is course format flexibility (online or face-to-face). Learning effectiveness is driven by employees having the option of choosing their preferred learning environment with a well known and respected University. Since many companies are global in nature, having online course options works extremely well for employees who travel extensively and is a necessary component to sustaining a successful relationship. An option for many of one company's employees is the opportunity to participate in their corporate sponsored evening education program. The PMBA program currently offers one, threehour evening course during the Fall and Spring semesters onsite. This onsite face-to-face classroom learning format is convenient for many employees who do not want to travel offsite for class. Other employees choose to participate in courses offered offsite at one of the other PMBA campuses as well as online because they wish to accelerate their progression through the program or because they desire student perspectives outside of the company. One company has suggested that UMASS Amherst offer more hybrid courses within the PMBA blended program.

Employees of another corporate partner also value the opportunity to choose their preferred method of learning. One company manager acknowledged that, "we each learn differently and UMASS understands the need for multiple delivery options. Our employees can attend on campus at different locations, attend classes entirely online, or in many cases a blend of the two methods is offered. This is extremely helpful for those employees who travel.”

Corporate representatives also feel that the PMBA educational partnership has helped increase employee retention through providing a high quality, reputable MBA program with relevant course material and outstanding faculty. The company selected the UMass PMBA as an educational partner because of reputation, faculty, national and international accreditation, and cost.

Two companies expressed that the primary benefits of being an educational partner with the PMBA 
program are: responsiveness and full cooperation of Isenberg Program Administrators, Faculty, and Staff; and trust and willingness to work as a team to promote and enhance the relationship and educational offerings for their company and employees.

PMBA students and faculty perceive significant benefits from the program. For students, the program boasts a diverse and experienced group of students that enrich the learning experience. The program's course format flexibility offers a wide range of opportunities for optimal learning, facilitated by quality and engaged faculty, and offered at a reasonable cost.

Faculty enjoy how the wide range of student perspectives and experience enrich the teaching and learning process. Similar to the students, faculty also appreciate the program format flexibility which enables them to more effectively manage their teaching, research, and personal schedules. Faculty also remark how the program is well supported throughout the university.

In summary, we have found that the PMBA has several common perceived benefits among Student, Faculty, and Educational Partnership populations. First and foremost is the flexibility in choosing course format that best facilitates learning effectiveness. All constituencies agree that having both face-to-face "traditional" classroom format coupled with the option of taking online courses is of great benefit to understanding and learning. The diversity in which these two formats expand a student's global business perspective is perceived as extremely beneficial to learning effectiveness and employee retention. Second, the quality of Isenberg faculty plays a significant role in the student experience. Third, the effectiveness of the PMBA Program Administrators coupled with the support received by Students, Faculty, and Educational Partners from the University, staff, and supporting departments positively impacts program success. Educational partners feel their administrators and employees receive excellent customer service from the program. When reviewing program options across the board, program accreditation and University reputation play major roles in choosing the PMBA program over competitors.

It is evident from student, faculty, and corporate perspectives that the PMBA program positively impacts and satisfies the needs of each constituency on a global and regional basis.

\section{B. LinEAP (Leadership in Educational Advancement Program): UMass Lowell Casewriter Judith Boccia}

LinEAP is a customized educational administrator licensure program collaboratively developed and offered by the University of Massachusetts Lowell Graduate School of Education and the Lawrence, MA Public Schools and facilitated by the university's Center for Field Services and Studies. The goal for Lawrence is to "grow" a cadre of its own school leaders and supervisors to meet future leadership needs in the district. Two cohort groups, totaling 39 Lawrence Public Schools educators, have participated to date. Currently, over half the LinEAP participants have been promoted to leadership roles in the school district.

LinEAP consists of 6 courses, including 5 academic offerings and a full-year supervised practicum that is the equivalent of one course. Four courses are primarily online, with monthly face to face meetings at a school in Lawrence; the fifth is a hybrid course, with weekly face to face meetings and online discussions and chat. The practicum is a faculty supervised and district mentored administrative experience in the Lawrence schools with an online component. The program takes $2 \frac{1}{2} 2$ years to complete, including summers. Students who complete the sequence of courses satisfactorily are recommended for state administrative licensure by the university and eligible for administrative appointment in the Lawrence 
Public Schools. While it is possible to earn administrative licensure at the university in exclusively face to face or online 10 course programs, LinEAP is currently the only means available to do so in a 6 course sequence consisting of a cohort enrollment, customized content, and blended learning.

Student and faculty assessment of the program was consistently positive. The cohort model with educators from varied schools and grade levels in Lawrence gave participants a framework for understanding the entire school system and a structure for building community. The cohort also helped working teachers manage a demanding program by creating a group identity and providing peer support for learning. Further, the monthly face to face sessions provided an opportunity to develop professional and personal connections with colleagues from throughout the district. Some of these connections have endured and matured into close friendships that provide support both in work and in personal lives even after the program is finished. Shared knowledge, understanding, and commitment around leadership in urban schools are distinctive outcomes of the LinEAP cohort experience, according to students and faculty.

The exclusively Lawrence membership of the cohort was generally seen as a strength of LinEAP since it allowed participants to learn with colleagues who face the same challenges in the workplace. In addition, the cohort's shared experience with the Lawrence Public School district's curriculum and instructional programs gave faculty a basis for developing relevant course material and a source of field based assignments. While course content addressed broad educational theories and national issues, all faculty made use of Lawrence school administrators as guest presenters or co-instructors to bring a local, world of practice perspective into courses. The involvement of Lawrence administrators in classes also signaled to students the importance and relevance of the learning taking place, and indicated the district's commitment to "grow" its own leaders from this program. Indeed, the school administration sees this program as an essential means to shape its future leaders from individuals who are committed to the community and who will continue to serve it in new roles as principals and supervisors.

The blended nature of the program received high marks from students and faculty. Combining online learning with face to face meetings offered convenient access to courses and accommodated different learning styles within each cohort. Sharing of journal entries on a discussion board during the practicum, for example, provided students peer support as they encountered challenges in the many different schools where they were assigned. Faculty found that online discussion gave students time and opportunity to reflect on their learning, something not always possible in face to face classes. At the same time, face to face meeting in schools brought university faculty into schools and put them in the real world of schools while giving participants from different grade levels and schools the chance to experience the work environments of colleagues. In addition, face to face meetings promoted group identity and supported online learning projects.

In addition to program specific features, individuals who facilitated faculty and student work were credited with LinEAP's success. The university's course development and technical support teams received high marks from faculty and students for making the online experience smooth. Course development specialists worked closely with faculty to create their online course materials, and continued to be available throughout the semester to troubleshoot and advise. Similarly, the university's online technical support desk was always available to assist students with technical issues in accessing online courses. All respondents also agreed that the presence of a liaison between the university and the Lawrence Public Schools was vital to the program's success. The liaison not only oriented students to the program, but also handled all the bureaucratic details associated with registration, scheduling, billing, book purchase and state licensure application. Additionally, he was able to access the leadership of both organizations to resolve questions, provide feedback from students, and plan for future courses and cohorts. 
LinEAP is a cost-effective means for the school district to develop a cadre of future leaders and for the students to earn state licensure as principals or supervisors. The district pays all tuition and fees for the program, in exchange for a promise from students to work three years in the district after completing their study. Those who do not must repay the costs to the district. To date, two individuals have left the district and have repaid their tuition and fees. Students report the cost-free nature of the program, as well as its competitive admission and promise of promotion to higher salaried positions, are significant incentives to participate. The district leadership feels that subsidizing LinEAP is a solid investment as the costs of hiring, training, and retaining an outsider in a leadership role is significantly higher than the tuition and fees for a single student in the program. For the university, LinEAP is also cost effective since no new personnel needed to be hired and the courses generate revenue. The $2 \frac{1}{2}$ year sequence of courses, with guaranteed enrollment, facilitates faculty scheduling and provides a pipeline of graduate students into the educational administration degree programs.

LinEAP's distinctive use of program co-design and course co-instruction with the client district has the potential to alter the way professional education curriculum and instruction takes place. While adhering to state and national standards for administrative licensure, LinEAP provides a customized course sequence of local relevance to one urban school district. There is no reason to believe this model could not be replicated elsewhere, provided faculty are willing to adapt their courses and their practice in response to school district needs.

\section{Online RN-BS: UMass Boston Casewriter Kathleen Polley}

Statistics indicate that about half of the nurses graduating from nursing education programs in Massachusetts were prepared at the associate degree level [15]. However, recent research points to the significant positive impact that baccalaureate-level nursing education can have for employers and patients [16].

Despite this research and employers' call for nurses to be prepared at the baccalaureate level, UMASS Boston experienced a decline in the number of registered nurses applying for admission. RNs voiced concerns over the difficulty with transfer credits, frustration with the repetition in course work, the rigidity in scheduling and the span of time needed to complete their degree. In an effort to meet the needs of the students and increase access (recruiting, retaining and graduating) for students who were challenged by family obligations, work schedules, and geographic distance, the College of Nursing and Health Sciences at UMASS Boston developed an Online RN-BS. The goal of the program is to increase the number of baccalaureate-prepared nurses by 150 RNs per year. The Program seeks to achieve this by forging partnerships with the community colleges in Massachusetts; designing culturally competent RNspecific curriculum; combining user-friendly distance technology with face-to-face interactions at pedagogically intentional junctures in the program; and community-based learning. It is critical that these goals are achieved while decreasing institutional barriers to remote students at an affordable cost.

Administratively, the program is designed to be a self-supporting. Financially it bridges the policies and procedures structured for the state-funded University and the self-supporting corporate structure of Corporate, Continuing, and Distance Education (CCDE). Program content is delivered through the auspices of CCDE, who provides the learning management platform, instructional design support services and the support for the synchronous environment. The Department of Nursing retains control of the program including admission and progression standards, curriculum and faculty selection. There have been an abundance of opportunities to reassess systems and processes of both CCDE and the University to meet the needs of the online students which have also enhanced the interface with the University for the traditional face-to-face student. 
The Online RN-BS Program has prerequisites that are met with most associate degree granting programs. Upon license verification students are awarded 38 credits for passing the NCLEX examination which demonstrates proficiency in their associate degree nursing course work. Students are then eligible to start the nursing sequence of courses. In addition to other general education courses, there are five six-credit nursing courses that are offered online which meets the university residency requirement. The program is designed to take eighteen calendar months to complete and currently costs $\$ 8700$, including tuition, fees and books.

Ninety percent of the students in the Online RN-BS program reside in Massachusetts. These students are challenged by family responsibilities, work demands, financial constraints and living geographically remote to a four-year university. The students report the appeal of the program is that it allows for anytime, anyplace learning demanded by their personal schedules and work. The reputation of the University of Massachusetts Boston Nursing Program also increases nurses’ desire to enroll.

Community college partnerships with UMass Boston serve a vital role in providing student access to affordable education. Seven articulation agreements between UMass Boston and area community colleges allow for a seamless transition to a baccalaureate education. The seamless transition is partially facilitated by academic advising sheets developed to list the courses at the community colleges that can be taken to fulfill the prerequisites of the Online RN-BS Program prior to applying for admission.

Another notable aspect of this RN-BS program is that once a student is admitted to a nursing cohort they are required to attend a face-to-face technology and University orientation hosted by the Director of the Online RN-BS Program. While familiarizing themselves with the tools used in online learning, students build bridges with their peers which are then expanded through the design of the curriculum. The average student comes to the program with significant deficits in their technological skills which are addressed during the orientation. Additionally, the cohort model of the program allows students to form bonds with one another. If nurtured and sustained, the relationship among students provides a network of support that encourages retention in the program.

The Online RN-BS makes optimal use of both synchronous and asynchronous tools. The synchronous environment is one way to build relationships among students and the design of the curriculum builds upon the foundation established during the face-to-face orientation. The various communication tools help students feel a sense of connection. A synchronous text chat environment is available 24/7 and is frequently used for group projects, just for students to socialize, or during weekly synchronous sessions. The Online RN-BS program uses the synchronous environment with each weekly session. Student attendance in the virtual classroom is not mandatory but it has a $95 \%$ attendance rate for each of the five classes in the program. The synchronous environment allows student access to community leaders and content experts who would otherwise not have that opportunity for interaction. Sessions are recorded for students who wish to listen to the classroom interaction asynchronously at a later time. The recorded sessions capture the student attendance, student/instructor interchanges between students, the whiteboard, PowerPoint lectures, and peers' use of emoticons. Threaded discussions give students the opportunity to be both learners and resources for the course content. This pedagogy is repeated throughout the program.

Community-based learning, including contributions by content experts, enhances the workforce development and localness aspects of the Online RN-BS Program. Recognizing students as both learners and resources takes advantage of students' work environment and gives other students a view into some of the top healthcare organizations in the country. Industry leaders are available within the area to participate in both the synchronized classroom and through video streaming. Involvement of regional 
health-care employers as hosts of student orientation sessions, contributors to instructional experiences, providers of community-based learning, and employers of UMass Boston students signals the embedded nature of the program in the region.

The design of the Online RN-BS program is meant to make an intimate connection among the students in the program, the professors teaching in the program, the Program Director, and community-based constituencies. Without the online component of the program most of the RNs would not be able to continue their education due to the need for flexible scheduling. This is an exciting program that in 24 months has met enrollment goals and graduated two cohorts of students.

\section{Women's Studies (WMS) Program: UMass Dartmouth Case Writer Jen Riley}

The UMass Dartmouth Women's Studies (WMS) Program offers a minor degree program fully online via the Division of Professional and Continuing Education (PCE). WMS online students, the majority of whom live in Massachusetts, fit into two categories: adult learners and traditional age students. While all students interviewed have experienced both face to face and fully online courses, the consensus is that online courses offer more convenience for working women with families and enable degree progress. Students value the ability to take classes, remain assets to their employers, and meet family needs. For example, one student noted that "it's easier for to participate in an online environment because, as a full time mom, wife, and employee with an already hectic schedule, [she has] more opportunities to access each course at [her] convenience." Another student commented that WMS online courses offer "more interaction and ideas sharing among the students" in comparison to other courses. Students observed that the WMS online courses were challenging; as one student stated, the courses were "more thoughtprovoking" and "online courses have strengthened my writing skills as well as my reading interpretation skills.”

Significantly, program cost is not a factor and each student believes that the online experience has transformed their educations. As one student commented, she might not have returned to higher education without the option for e-learning, while another student noted that she prefers all online courses since "if they are set up correctly, they offer much more interaction and collaboration than what I've found in my traditional on campus PCE courses." Another student stated that online learning brought her back to school fulltime.

The four faculty interviewed value the intellectual engagement WMS courses offer them, and they recognize the program appeal to non-traditional returning women students who would not otherwise have educational access. Each faculty member believes that e-learning offers benefits. For example, while two faculty members regret the loss of spontaneity in face-to-face classroom discussions, the same faculty members realize that the online format creates discussions where all students have to participate. One faculty member suggested that students "need to be prepared to exercise a certain degree of flexibility in the "real world" and "mixing up" their learning opportunities and responsibilities will help them do that." Furthermore, online teaching, as one faculty member noted, requires faculty "to examine one's own pedagogy," a key ingredient that has improved teaching practices.

Faculty agree that the WMS program supports them in developing courses and providing resources. A significant issue for faculty is class size, and faculty firmly stated that to maintain what one called "the integrity of the learning that occurs online," an enrollment cap of 20 students per fully online course must remain in place. Each faculty member also asserted that the workload for fully online courses is 
significantly higher than a face to face class, something they believe administrators fail to understand.

The WMS Program is meeting its mission to provide educational access for adult learners in the South Coast region. The online format, as one administrator commented, is "one of the most exciting avenues to support this work" as online opportunities "enable adult learners to manage their personal, professional and education needs." In addition to providing course access, the WMS online program is transforming students and faculty. Students assert that the WMS courses are structured, rigorous learning experiences that add to personal growth. Faculty note that learning to teach effectively online has forced them to reflect on student progress and how they assess their courses. Support services meet student and faculty needs. Students report no difficulties with enrollment services, financial aid, the registr ar, or bookstore. Additionally, students indicate that access to library resources is effective. Faculty indicate that the university support systems are responsive to technical needs and questions.

As with any initiative, limitations exist. Further development is needed in the areas of curriculum, course scheduling, online course development, and course partnerships with the Colleges of Business and Nursing. Development incentives for faculty will be necessary to broaden the scope of the online course offerings. Also, PCE students need assistance in understanding the value of the minor degree. Yet, the 3year old program, as evidenced by steady enrollments, has solid roots. Most importantly, students, in particular non-traditional women students, are experiencing transformative learning experiences, which have brought them back to the university and helped them progress toward degrees and personal goals.

\section{NEW POPULATIONS TO BE SERVED}

Asynchronous online education has opened opportunities to millions of learners around the world who were willing to give up face to face interactions with their faculty and peers for the convenience of learning anytime, anywhere. While we anticipate continued growth in this area, we believe that there is a tremendous opportunity to increase access by developing programs that intentionally blend face to face and online services and courses especially when the services and courses are tailored to meet the needs of a local constituency.

There is increasing evidence of the demand for such programs including a recent study released by Eduventures and Sloan-C [17, 18, 19]. Evidence indicates that even asynchronous online students enroll with institutions that are closest to them geographically. This trend reveals a seemingly natural desire for students to affiliate with a bricks and mortar campus. For example, UMass Lowell Master's degree in Educational Administration had very low enrollments until the faculty reluctantly agreed to move the program online. Within a year, the program yielded record growth in enrollments and quadrupled the number of students matriculated in the program by the $2^{\text {nd }}$ year. Analysis of zip codes for those enrolled, revealed that the majority of the students lived within commuting distance of the school. Clearly proximity to a local institution made the difference for these students who decided to enroll in the Lowell program.

The cases reviewed suggest that intentional and creative uses of combinations of online courses, services and programs with face to face courses, services and programs will attract new audiences to higher education. However, institutions will benefit from principles and frameworks that will guide their work. In much the same way that early research on asynchronous online education helped institutions to create successful quality asynchronous learning networks, research on blended learning and localness can help inform future development of programs to meet local needs. 
Drawing from the characteristics outlined above, we would like to offer the following themes that emerged from the cases and research:

1. Local blended programs should be driven by an institutional mission to serve the local region and engage local/regional partnerships to build curricula that are contextually responsive.

2. Local blended programs can and should take advantage of low-cost marketing strategies available through local relationships and brand.

3. Many students prefer to have some blend of face to face and online services and instruction threaded throughout their college experience as long as it is intentional, leading to improved access and learning effectiveness.

4. Faculty enjoy working with partners to develop local blended programs tailored to meet the needs of local constituencies and organizations when the efforts are mission driven and supported by the institution.

5. Access is greatly enhanced when local blended programs provide students with an activity (such as face to face orientations) or person that anchors the student to the campus and program.

\section{FUTURE DIRECTIONS}

A new generation of programs that combine elements of asynchronous education with blended learning and campus based services has emerged which address the existing skepticism and enhance access by providing a rich mix of face to face activities, learning experiences and services with online activities, learning experiences and services.

The cases reviewed in this article serve as exemplars of the kind of creative program development institutions might engage to take advantage of the local competitive edge.

Hopefully, the Framework for Characteristics of successful Local Blended Programs proposed in the article will serve as guide for developing quality local blended programs. However, the framework needs to be further researched and defined to determine its applicability and effectiveness as a framework for building and assessing local blended programs.

This article shows that institutions can serve new audiences by developing quality blended programs tailored to meet the needs of local students and/or regional organizations and businesses. Developing programs and marketing along this framework will enable institutions to deepen their portfolio of programs and services and thereby expand their prospective pool of students and the quality of their programs. Creative and responsive marketing that addresses the student needs for local affiliation with institutions in their region should give local institutions a competitive edge against outside competitors. Finally, we all should continue to seek and highlight examples of successful local blended programs as we have done here, and use the framework to intentionally build and scale for greater access and localness.

\section{ABOUT THE AUTHORS}

Jacqueline F. Moloney is the dean of the Division of Continuing Studies, Corporate and Distance Education at UMass Lowell, and Executive in Residence for UMassOnline. She is known for her leadership in online education, innovation in curriculum and instruction, entrepreneurship and assessment. After founding the Centers for Learning and the Faculty Teaching Center at UMass Lowell, she went on to redesign its traditional continuing education program into a highly successful professional education 
program known for its quality, responsiveness to students and business and for its high caliber online education programs. Under her leadership, UMass Lowell's online programs developed a national reputation for its quality and received two prestigious awards from the Sloan Consortium for Outstanding Faculty Development and Outstanding Institution-wide Programming. In addition, she has crafted numerous innovative partnerships with business and industry that have yielded impressive results for the Lowell campus.

As a member of the Board of Directors for the Sloan Consortium of Asynchronous Learning Networks, Moloney has served as a contributor to the national dialogue on the emergence of online learning programs. She has served as a member of numerous professional organizations including the AACU, and the American Association of Higher Education and is on the Board of Directors for the Merrimack Valley Venture Forum. Moloney has authored numerous articles on the development and assessment of online programs, the use of technologies in the classroom; cross-disciplinary approaches to curriculum reform; and the organizational reform of higher education. She is committed to community involvement and has served on numerous civic boards including the Greater Lowell Community Foundation, House of Hope, Girls Inc. and Whistler House.

Charmaine P. Hickey has worked for twenty years in public higher education and earned her Ed.D. in Leadership in Schooling from the Graduate School of Education at University of Massachusetts Lowell. She is currently Director of the Faculty Teaching Center at University of Massachusetts Lowell and Project Director for a UMass system-wide Alfred P. Sloan Foundation Grant for Local Blended Learning. Her wide array of educational interests include teachers' efficacy beliefs, transitions in higher education, faculty development, and technology.

Amy L. Bergin is director of marketing, business development and professional programs at UMass.

Judith Boccia is Director of the Center for Field Services and Studies at the University of Massachusetts Lowell. She received her Ed.D. from Teachers College Columbia University, and also holds undergraduate and graduate degrees in English. Her work focuses on building and sustaining schooluniversity collaborative programs, including urban educator professional development and technology integration in support of curriculum, both topics on which she has written and presented widely. She has also developed and taught several customized, blended learning courses for urban school districts, and continues to explore use of online resources to enhance course access and delivery.

Kathleen Polley RN MS is the Director of the Online RN-BS Program at the University of Massachusetts Boston. She graduated from Simmons College in 2003 with her Master's degree in Primary Pediatric Care. She has been a pediatric nurse for 25 years and worked in Pediatric Critical Care and Pediatric Oncology, Bone Marrow Transplant. She has held various staff and management positions at Children's Hospital, Seattle: Mary Bridge Children's Hospital, Tacoma Washington and Lucille Salter Packard Children's Hospital, Palo Alto, Ca. She began teaching in 2003 and in 2004 implemented the first online undergraduate degree at the University of Massachusetts Boston and became Director of the Online RNBS Program in 2005. The Online RN-BS Program was developed to meet a workforce development need within the Commonwealth of Massachusetts.

Jeannette E. Riley is Associate Professor in English \& Women's Studies at the University of Massachusetts Dartmouth. She earned her Ph.D. in Contemporary American \& British literature and literary theory in 1998 from the University of New Mexico. Riley’s research and teaching focuses upon post-1945 American literature, contemporary women's literature, and feminist theory. In addition, Riley 
directs the Women's Studies program. Riley has published articles on Irish poet Eavan Boland, Adrienne Rich, Toni Morrison, Terry Tempest Williams, and Wallace Stegner, as well as articles on feminist pedagogy and online teaching.

\section{REFERENCES}

1. Allen, I. E. and J. Seaman. Growing by Degrees: Online education in the United States. Needham, MA: Sloan-C, November 2005.

2. Garrison, D. R. Online collaboration principles. Journal of Asynchronous Learning Networks 10(1): 2006.

3. Otte, G. and M. Niemiec. Blended learning in higher education: A report from the 2005 Sloan-C workshop. Paper presented at the Second Sloan-C Workshop on Blended Learning, Chicago, IL, April 17-19, 2005.

4. Garrison, D. R. and H. Kanuka. Blended learning: Uncovering its transformative potential in higher education. Internet and Higher Education 7(1): 2004.

5. The Sloan Consortium mission statement. http://www.sloan-c.org/aboutus/index.asp.

6. Moore, J. C. (Ed.) ALN principles for blended environments: A collaboration. The Sloan Consortium, 2004.

7. Mayadas, A. F. Blended, ALN, and localness initiative, n.d.

8. NVivo ${ }^{\circledR}$. http://www.qsrinternational.com/products/productoverview/NVivo_7.htm

9. Glaser, B. G. and A. L. Strauss. The Discovery of Grounded Theory Strategy for Qualitative Research. Hawthorne, NY: Aldine, 1967.

10. Maxwell, J. A. Qualitative Research Design: An Interactive Approach. Thousand Oaks, CA: Sage, 1996.

11. Boccia, J. A collaboration of the University of Massachusetts Lowell Graduate School of Education and the Lawrence (MA) Public Schools: A case study. LinEAP (Leadership in Educational Advancement Program), Unpublished case study, 2006.

12. Polley, K. Online RN-BS Program at the University of Massachusetts Boston, Unpublished case study, 2006.

13. Bergin, A. University of Massachusetts Amherst Isenberg School of Management Professional MBA Program, Unpublished case study, 2006.

14. Riley, J. UMass Dartmouth's Women's Studies Program and Division of Professional and Continuing Education: An e-learning initiative, Unpublished case study, 2006.

15. Massachusetts Board of Registered Nurses. Admissions, graduations and enrollments, 2003. Retrieved September 12, 2006 from http://www.mass.gov/?pageID=eohhs2terminal\&\&L=4\&L0= Home\&L1=Researcher\&L2=Physical+Health+and+Treatment\&L3=Nursing+Statistics\&sid=Eeohhs2 \&b=terminalcontent\&f=dph_quality boards_nursing $r$ _stats admissions enrollment\&csid=Eeohhs2.

16. Aiken, L. H., S. P. Clarke, R. B. Cheung, D. M. Sloane and J. H. Silber. Educational levels of hospital nurses and surgical patient mortality. Journal of American Medical Association 290(12): 2003. http://www.jama.com.

17. Eduventures. Expanding demand for online higher education, part 1: Assessing consumer views and experiences. Catalog No.3OHECR0806. Boston, MA: Eduventures, LLC, 2006.

18. Eduventures. Expanding demand for online higher education, part 2: Understanding the sample. Catalog No.3OHECR0806. Boston, MA: Eduventures, LLC, 2006.

19. Allen, I. E. and J. Seaman. Entering The Mainstream: The Quality and Extent of Online Education in The United States, 2003 and 2004. Needham, MA: Sloan-C, November 2004. 